Forbes, J. \& Maxwell, C. (2018) 'Bourdieu plus: understanding the creation of agentic, aspirational girl subjects in elite schools', in G. Stahl, D. Wallace, C. Burke \& S. Threadgold (eds) International Perspectives on Theorizing Aspiration: Applying Bourdieu's Tools. London: Bloomsbury.

\title{
Bourdieu Plus: Understanding the Creation of Agentic, Aspirational Girl Subjects in
}

\section{Elite Schools}

Joan Forbes and Claire Maxwell

\begin{abstract}
This chapter draws on Bourdieu's concept of 'habitus' as both focus of analysis and analytical method to examine how an elite girls' school in Scotland shapes its students' aspirations by producing intellectually able, socially connected and self-reflective young women. Taking a hybrid approach, we extend our analyses by drawing on theorizations of space and time, agency, affect and reflexivity to understand the intensive institutional discursive and affective work to intertwine school and family. Insights are gained on how this school habitus works spatio-temporally, extending and usually successfully aligning with its students' anterior family habitus, to produce agentic and assuredly optimistic orientations. Informed by our earlier studies on girls' elite schooling in England and Scotland and analysing data from our current UK-based Leading Women Study, we make a case for our 'Bourdieu-plus' bricolage which loosely couples Bourdieu's concepts with those of other social theorists. This approach, we argue, is generative of new and more nuanced insights on how habitus fosters and embeds aspirations.
\end{abstract}

Keywords: Family habitus, institutional habitus, agency, affect, aspiration, gender, spatiotemporality, reflexivity

\section{Introduction}


Forbes, J. \& Maxwell, C. (2018) 'Bourdieu plus: understanding the creation of agentic, aspirational girl subjects in elite schools', in G. Stahl, D. Wallace, C. Burke \& S. Threadgold (eds) International Perspectives on Theorizing Aspiration: Applying Bourdieu's Tools. London: Bloomsbury.

This chapter examines the social and intellectual habitus of Wagril (a pseudonym), an elite 'all-through' (ages 3-18) school for girls, located in Scotland. In what follows we operationalize theory to explore how elite education can facilitate the development and realization of aspirations. Through drawing on Bourdieu's concept of habitus (e.g. Bourdieu 1977, 1996), we examine how the Wagril institutional habitus works spatio-temporally to extend the family habitus and, in doing so, supports the emergence of girls' agentic selves. The girls' belief in their capacity to act, and the examples set by those who successfully achieve within their families and through the school, is critical in fostering their aspirations and a surety about the future in terms of higher education, work and social networks (Maxwell and Aggleton 2013a; Forbes and Lingard 2015).

We argue Wagril is a carefully constructed school space that combines the academic with more practical experiences. The school's dining room, for instance, combines the 'civilizing' and largely socio-community practices of eating together with hearing from 'old girls' about the future world that awaits today's Wagrilians. Families are regularly invited to join students and teachers in these events. These are carefully constructed to align students' (family) experiences with the institutional culture (i.e. the habitus and field) in order to embed this developing habitus of agentic aspiration and make it a more durable part of the habitus.

This chapter is informed by our previous work on the elite education of girls in Scotland and England. Wagril was one of the three schools involved in an earlier study of elite education in Scotland, the Scottish Independent Schools Project (SISP) (see e.g. Forbes and Weiner 2008). The SISP project used a case study methodology, comprising a number of different data collection tools - document analysis; observations; fieldnotes; semi-structured interviews; and a short questionnaire (see Forbes and Weiner 2014). Wagril's students are predominantly day pupils who reside locally, within the limits of the city in which the school 
Forbes, J. \& Maxwell, C. (2018) 'Bourdieu plus: understanding the creation of agentic, aspirational girl subjects in elite schools', in G. Stahl, D. Wallace, C. Burke \& S. Threadgold (eds) International Perspectives on Theorizing Aspiration: Applying Bourdieu's Tools. London: Bloomsbury.

is based, as well as the surrounding rural areas. It has accommodation for about fifty boarders from wider afield in Scotland and other countries. The ethnic profile of Wagril is predominantly white Scottish and white British.

We have extended elements of the SISP project, particularly our work at Wagril, through our current Leading Women study - where we focus on how female headteachers conceptualize elite education and lead their schools. Some of the interview data analysed here comes from the latter research, where we re-interviewed Wagril's now retired headteacher. We have also drawn on our first interview with the headteacher, the student survey data (of all 13-14 year olds in the school) and school documentation (from magazines, prospectuses and their websites) from SISP.

Following Bourdieu, we work with the concept of habitus - both as a method for analysing our data, but also as the focal point of what it is we are studying (Reay 2004). Habitus is understood here as the embodiment of particular historical cultural experiences that shape dispositions, which, in turn, may drive certain practices. We conceive of all practices as enactments of agency, and highlight the role of affect in this process (Maxwell and Aggleton 2014a). Affect here, we argue, shapes and characterizes relations between people, as well as people and objects. We see affect as a different concept to emotions, which captures the kinds of feelings that are experienced, or observed on or within the body/a person (Maxwell and Aggleton 2013c). Thus, Clegg (2013) argues that emotions are something people have, but these are socially constituted by the affective structures that shape how these 'emotions' are experienced.

The habitus is initially strongly shaped by family (Reay 1998, 2004; Archer et al. 2012), but is subsequently further embedded or challenged through a subject's interactions with different fields. Where family dispositions align with the institutional habitus of the school (Bourdieu 1996: 44), we argue that this particular type of orientation to the self, others 
Forbes, J. \& Maxwell, C. (2018) 'Bourdieu plus: understanding the creation of agentic, aspirational girl subjects in elite schools', in G. Stahl, D. Wallace, C. Burke \& S. Threadgold (eds) International Perspectives on Theorizing Aspiration: Applying Bourdieu's Tools. London: Bloomsbury.

and the future is more likely to 'stick' (Maxwell and Aggleton 2014b). Ahmed emphasises that affect is 'what sticks' (2010: 29), so we see the affective nature of the spaces created within the school and the relations being fostered there as central to the process.

Another central element in our deployment of Bourdieu's theorizations of habitus is his emphasis on how the past is likely to play a role in informing the future. For Bourdieu: the habitus is the product of history; history produces individuals and collective practices. The 'system of dispositions' constitutes 'a past which survives in the present and tends to perpetuate itself into the future ...' (1977: 82). Thus, in our research we examine closely how family has shaped the habitus of the girls studying at Wagril, and then trace how the habitus becomes challenged, further embedded and/or moulded through their time at the school. The interactions between family and school habitus, in turn, prepare the ground for the dispositions the girls take with them into their future lives (Bourdieu 1977; Maxwell and Aggleton 2014b). Anterior family and institutional influences are therefore 'restructured but not erased' (Brubaker 1993: 226) as these privileged young women move into higher education and work, and start their own families. In this chapter we argue that, where family and institutional habitus are closely aligned, it is more likely that a fairly clearly articulated set of dispositions and congruent practices will emerge that inform future desires, interactions and destinations.

Extending Bourdieu's conceptual toolkit, we understand the relationship between habitus and aspiration as particular spatio-temporal investments constituting specific ideals and commitments towards the future. Thus, students' aspirations for expected futures are already present, generated in the spatio-temporalities of their habitus. In the words of Bourdieu, the future is already to a certain extent inscribed in the present; today's practices significantly influence what is to come. However, our research has focused on seeking to understand more fully the ways in which the present interacts with the past and therefore 
Forbes, J. \& Maxwell, C. (2018) 'Bourdieu plus: understanding the creation of agentic, aspirational girl subjects in elite schools', in G. Stahl, D. Wallace, C. Burke \& S. Threadgold (eds) International Perspectives on Theorizing Aspiration: Applying Bourdieu's Tools. London: Bloomsbury.

embeds and/or re-moulds the habitus of young women being educated in elite schools. In this way we can start to understand more fully the processes of social reproduction, but also potentially of social mobility, that are facilitated through different kinds of elite education as young women/people take another step through the 'institutional wormholes' (Nespor 2014) of elite reproduction.

Despite the intense debates among Bourdieusian scholars about whether the concepts of family habitus and institutional habitus are coherent with his theoretical framing (see e.g. Reay 1998; Atkinson 2011; Burke, Emmerich and Ingram 2012; Tarabini, Curran and Fontdevila 2016), for our purposes we find both notions helpful in thinking about the effect the young women's immersion in these two spaces has on their orientations to the future. We seek to understand how family and school offer particular ways of knowing and being, and specifically how the interactions between these two spaces - of family and school - unsettle or reinforce their understandings of the world, their desires, their interactions with others and the trajectories they seek to forge into their futures.

The concepts of both habitus and institutional habitus are critical for us in making sense of processes of social reproduction (Bourdieu 1977). However, in our so-called 'Bourdieuplus' approach, we seek to provide further insights into the underpinnings of Wagril's particular articulation of an elite aspirational habitus by drawing on other theoretical inflections, such as those relating to space, the sticky-ness of affect and a reflexive disposition.

\section{Family and Aspired to Futures in School: Habitus Knittings that Stick}

I worked with the architecture ... two listed buildings ... the buildings are just as much part of the learning ... and what we did was ...- turn it into a campus ... and people can live and move and different ages can live and move around 
Forbes, J. \& Maxwell, C. (2018) 'Bourdieu plus: understanding the creation of agentic, aspirational girl subjects in elite schools', in G. Stahl, D. Wallace, C. Burke \& S. Threadgold (eds) International Perspectives on Theorizing Aspiration: Applying Bourdieu's Tools. London: Bloomsbury.

and feel they're coming to this sort of really [lovely place] ... We thought ... if we could get an eating [space] that would open it up, feeling you know, here is this building [the community centre] which is for living and open. (Headteacher (HT), Interview (Int.) 1)

Introduced above, the community centre was very specifically designed and built as the hub of Wagril. It represented the centre of the social and intellectual life of the school. The school community centre was central in the social practices of the daily thrum or rhythm of school life (hence our emphasis on spatio-temporalities as a concept: Lefebvre 1991; Massey 1994; Forbes and Weiner 2012). The centre also served to strongly link and merge home and school, with parents often having breakfast there with their daughters before classes, and the headteacher ever present to mingle and chat with all. In this way, the affective atmosphere created in this space sought to ensure families felt themselves to be a central part of the school, where their expertise and desires could be shared. Parents were therefore asked to invest their time and energies into the educational endeavour of the school. These regular moments of bringing family and school together in the young women's lives meant the link between family and school was strengthened affectively. Furthermore, because these interactions were occurring within the school space itself, these moments of sociability opened up opportunities for the institutional habitus to influence the families' ways of thinking and being.

Wagril's intensive social-spatial 'knittings' included conscious work with and through the school's elegant architecture to open up re-designed historic buildings, and to create architect-designed physical spaces that aimed to 'effortlessly' facilitate these critical social and intellectual moments. The aesthetic surroundings at Wagril were aimed at promoting ease, wellbeing and proactive participation, and inculcating dispositions that would, we would argue, 'stick' into the future. 
Forbes, J. \& Maxwell, C. (2018) 'Bourdieu plus: understanding the creation of agentic, aspirational girl subjects in elite schools', in G. Stahl, D. Wallace, C. Burke \& S. Threadgold (eds) International Perspectives on Theorizing Aspiration: Applying Bourdieu's Tools. London: Bloomsbury.

The [community centre] developments were always intended to provide better facilities for teaching and learning, to improve the school's ethos and social life and to enable sharing with others. We could have the kind of setting that enabled students to feel that they were in almost a university world ... With proper, inviting and appropriate facilities, boys and girls from neighbouring schools joined the students for drama, music, sport, social life, lectures, action, research, projects, trips. (HT, Int. 2)

The centre hosted myriad events during all parts of the day from morning breakfast to latenight opera. The community centre was the intellectual, cultural and social hub of the school's expansive spatio-temporalities, facilitating social interactions between family, school, and representatives of local and national cultural and social elites. Thus, a particular social and intellectual institutional habitus was being facilitated that aimed to extend the families' habitus and be carried over in post-school habitus. Critical in securing the effective inculcation of a particular habitus was the role of the headteacher. Beyond her presence within the formal curriculum and school day, the headteacher and her husband were always visible at the numerous cultural events held by and at the school, to be seen on the touchline at sporting fixtures shouting encouragement, and always talking animatedly and knowledgeably with girls and families.

Furthermore, attempts to knit together family and school can be seen in the discursive representation of the school. For instance, in a student survey conducted at Wagril, responses to the item 'School is like ...' received responses such as 'home', 'second home' and 'family'. Meanwhile, boarders at the school, just like the day pupils, were encouraged to 
Forbes, J. \& Maxwell, C. (2018) 'Bourdieu plus: understanding the creation of agentic, aspirational girl subjects in elite schools', in G. Stahl, D. Wallace, C. Burke \& S. Threadgold (eds) International Perspectives on Theorizing Aspiration: Applying Bourdieu's Tools. London: Bloomsbury.

view Wagril as their second home. Additionally, all employees of the school were expected to provide a 'pastoral', socially inclusive, caring attitude towards all students.

The headteacher emphasised that relationships across the school should be characterized by, in her words, interpersonal respect; trust and confidence; openness to others and to a range of ideas; involving and getting on with everybody and everybody 'counting'; liveliness; being available and relating to others; collaborating equally and leading collaboratively; being honest, capable, responsible, caring and dedicated; and valuing oneself, belonging and being of independent mind (HT, Int. 2).

Through numerous events, across different spaces within the school, and throughout the years the girls attended Wagril, the habitus of the young women was being moulded in very particular ways that would, in turn, shape their aspirations. The frequent and repetitive nature of these moments, the consistency with which particular values were affectively reiterated (as outlined by the headteacher above), is likely to ensure that a fairly stable habitus is promoted. Wagril therefore aims to promote alignment instead of disjuncture between family and institution, which is more likely to secure the particular habitus of its students.

We argue that by applying Massey’s (1994) conceptualization of scalar space-time we gain further analytical purchase and insights into how social and intellectual relations are constituted and in turn shape, among many other things, young women's understandings of 'the future' and their desires to become particular 'future-girl-subjects'. Massey argues that:

the spatial is thought of in the context of space-time and as formed out of social relations at all scales, then one view of a place is of a particular articulation of those relations, a particular moment in those networks of social relations and understandings. (1994: 5) 
Forbes, J. \& Maxwell, C. (2018) 'Bourdieu plus: understanding the creation of agentic, aspirational girl subjects in elite schools', in G. Stahl, D. Wallace, C. Burke \& S. Threadgold (eds) International Perspectives on Theorizing Aspiration: Applying Bourdieu's Tools. London: Bloomsbury.

Therefore, in understanding how aspirations are formed, we view social-intellectual relational space as 'scalar' in analysing spatio-temporalities production at different levels - different times, places and occurring with different rhythms in the school life. The use of a spatiotemporalities frame in analysis emphasises the scales at which we need to research, analyse and, in doing so, more fully understand the formation of habitus. Spatio-temporalities theorizations have provided us with the necessary analytical purchase to understand the effects of different spatial repetitive rhythms (Lefebvre 2004).

Furthermore, we contend that affective agentic resources are central to the Wagril headteacher's professional habitus and the school institutional habitus, which shape the structures moulding the Wagril girls' habitus (see e.g. Tarabini, Curran and Fontdevila 2016). We understand affect as driving and underlying agency - 'infusing and circulating around the space, the person and broader discourses' (Maxwell and Aggleton 2013b: 5). Following Bourdieu (1986), we view social-emotional affect norms as the mostly unwritten aspects of family and institutional habitus, inculcating the typical feelings we should have towards our social networks. Thus, affect structures the girls' affinities, engagements, motivations and broader dispositions, which inform each individual's future envisioning and actions.

\section{Habitus and Aspiration}

The girls' collective schooling habitus intensively inculcated personal and professional future-orientated dispositions. The girls' anterior family habitus was extended, but also modified or diversified in particular ways, through a Wagril schooling which lay down specific dispositions they should draw on when reproducing school-envisaged futures (Bourdieu 1977; Brubaker 1993). We argue that three particular aspects of the institutional habitus emerged that relate directly to the young women's capacity to aspire and to fulfil 
Forbes, J. \& Maxwell, C. (2018) 'Bourdieu plus: understanding the creation of agentic, aspirational girl subjects in elite schools', in G. Stahl, D. Wallace, C. Burke \& S. Threadgold (eds) International Perspectives on Theorizing Aspiration: Applying Bourdieu's Tools. London: Bloomsbury.

those aspirations: the promotion of a sense of agency, the use of affective resources, and the development of a reflexive approach.

\section{A Sense of Agency}

The school fostered a habitus which was grounded in a strong self-belief and high levels of self-esteem, a confidence and sense of efficacy about the self and the future - a positive agentic self (see also Gaztambide-Fernández, Cairns and Desai 2013). We view agency as accomplished by individuals in particular contexts, but facilitated by drawing on their available resources or, following Bourdieu, their stocks of capitals, viz. here: economic, social and intellectual (Bourdieu 1986, and see e.g. Forbes and Weiner 2008). Thus, individuals' capacity to act in a particular social context derives from their specific current and prior habitus-inculcated dispositions. The headteacher recalled:

Overall the students wanted to be themselves and articulate what they really cared about. If it was art, for instance, they would tell you that and they would be in on Saturdays for the art class with a life model. If it was sport, they would come to tell you and you would talk to them about their experience and their team. If it was academic work, they would tell you. You knew that they would be competent in themselves.

(HT, Int. 2)

We found these girls to be extraordinarily resourced with individually tailored stocks of capitals, and with the necessary underlying reflexive habits and trust relations with their teachers, so as to feel empowered to positively envision and work towards their futures. Our 
Forbes, J. \& Maxwell, C. (2018) 'Bourdieu plus: understanding the creation of agentic, aspirational girl subjects in elite schools', in G. Stahl, D. Wallace, C. Burke \& S. Threadgold (eds) International Perspectives on Theorizing Aspiration: Applying Bourdieu's Tools. London: Bloomsbury.

broader research at Wagril, viz., the student survey and focus groups interview data, found that these girls exuded confidence, which we have termed 'assured optimism', in being well equipped to pursue their desired futures (Forbes and Lingard 2013, 2015). Applying an analytical frame examining for social capital, using key terms including trust and confidence, our data again and again showed these students' high levels of self-confidence. For example, the data revealed that they assuredly and optimistically took for granted high levels of academic attainment, as well as broader co-curricular achievement. They saw public examinations success as a key means to navigate not only their tertiary education futures (seen as Oxbridge and Ivy League university destinations), but also beyond in terms of their individual professional futures and life choices around future marital partnerships and children.

\section{Inflected by Affect}

Wagril's institutional habitus foregrounds sociability and the formation of generative relations - particularly of 'soft power' relations regarding present and future leadership, and acting knowledgeably, authoritatively, but respectfully in relation to others. In and through Wagril's particular affective commitments and engagements, its girls consciously and reflexively understand and work with affect - their own and others' feelings - and critically seek out and expect 'to belong' in these elite, aspirational, meaningful spaces that the school works so hard to create for them. Through these positive affective experiences of caring for oneself and others and through a sense of rightfully 'belonging', the agentic aspiration self is more likely to emerge successfully and be sustained. 
Forbes, J. \& Maxwell, C. (2018) 'Bourdieu plus: understanding the creation of agentic, aspirational girl subjects in elite schools', in G. Stahl, D. Wallace, C. Burke \& S. Threadgold (eds) International Perspectives on Theorizing Aspiration: Applying Bourdieu's Tools. London: Bloomsbury.

One way in which the school foregrounds the affective structures that promote belonging and aspiration is to tackle the girls' sense of self and self-worth, and encourage them to 'talk'. The headteacher emphatically stated:

We know that women can easily be put down and are very self-critical ... In practice, we must give young women of every age the chance to become themselves, not to feel ashamed of anything about themselves ... some will be bitchy to their friends. That has to be approached [dealt with] and it is essential to talk to young women ... [about these various issues] in the appropriate context of trust. (HT, Int. 2)

Thus, informed by the headteacher and other staff, knowledge of reflexivity and values of trust and regard are promoted - made to stick - at Wagril with a view to equipping its girls with affective capacities for school success and aspired-to futures. The effects of girls' individual practices, their feelings of self-worth, and their extant affective social capital relations with friends and other members of the Wagril community (current and past pupils, family networks using the school and so forth) are understood and quite explicitly worked with here.

\section{A Habitus of Reflexivity Fostering Resilience}

Wagril's institutional habitus actively emphasised the importance of the intellectual habit of reflexivity, which was seen as a valuable capacity for the girls' futures. While scholars have engaged with ideas of reflexivity and habitus to date - see Sweetman's (2003) account of 'reflexive habitus', Adams (2006) for critical debate on habitus and reflexivity, and 
Forbes, J. \& Maxwell, C. (2018) 'Bourdieu plus: understanding the creation of agentic, aspirational girl subjects in elite schools', in G. Stahl, D. Wallace, C. Burke \& S. Threadgold (eds) International Perspectives on Theorizing Aspiration: Applying Bourdieu's Tools. London: Bloomsbury.

Threadgold and Nilan (2009) for further critique - here we draw on Archer's (2003) idea of the internal conversation to integrate reflexivity and affect into our theorization of an agentic and aspirational habitus. The internal conversation, which is prompted by the emotional responses that are elicited following any interaction, leads to a commitment to a course of action both in the present but which is also connected to future possible imaginings. In our work we have argued that if such a course of action is acted upon it constitutes agency (Maxwell and Aggleton 2014a). Thus, at Wagril, we found that the girls are inculcated into the habit of reflecting on their practices, seeking to understand the factors shaping these, the value of the outcomes of such practices and assessing whether to do things differently in the future. The headteacher explicated:

I take it for granted that an excellent school must have dedication to the development of the mind ... [Staff] would be working all hours and taking trips in holiday time. They were people who believed in their subject and their pupils, who would go the extra mile. They did all they could in giving support to pupils with extra abilities in maths, for instance, and equally to pupils with additional support needs ... Every teacher was concerned about the whole person. (HT, Int. 2)

Here, school structures, including the ongoing and committed support teachers offer (one aspect of the overarching institutional habitus), spatio-temporally underpin the laying down of particular habits of the mind.

Inculcation of mental resilience is underpinned by the constant practice of incarnating reflexive self-awareness. For example, Institutional 'Pastoral' Guidance (Personal and Social 
Forbes, J. \& Maxwell, C. (2018) 'Bourdieu plus: understanding the creation of agentic, aspirational girl subjects in elite schools', in G. Stahl, D. Wallace, C. Burke \& S. Threadgold (eds) International Perspectives on Theorizing Aspiration: Applying Bourdieu's Tools. London: Bloomsbury.

Education) efforts focused intensively on habits of reflexive thinking. The Wagril headteacher remarked for example:

I think students were generally able to articulate what they felt ... on the whole they would find someone to confide in ... I was told all the time what people were feeling like. This is the result of having exceptional women staff in charge of the ethos of the school. [The Deputy Head of Guidance] was sensible as well and often made it clear that their problem was part of life. Life is full of contradictions and sometimes it is going to go wrong for you: what is important is to tackle the issues and to find ways to overcome them. (HT, Int. 2)

The Wagril institutional habitus therefore inculcates the capacity to be resilient among its students, through the in-built habit of being reflexive, almost continuously. We observed this during our discussions with the young women, whose narratives were usually constructed in a reflexive manner as they talked about themselves, their relationships with others and their futures. The process of being reflexive was understood within the school to facilitate a form of tenacity in the girls' approach to life. Thus, Wagril girls were expected to be (or at least learn to be) resilient - even 'tough' on themselves; and, somewhat paradoxically, to be 'soft' and convivial in their orientations towards others.

The vast majority of Wagril girls, and their parents aspire to a form of schooling tuned in to the needs and (re)production of 'academic high flyers'. But it is the emphasis on agency, positive affective relations with others and being resilient - driven by the intellectual practices of reflexivity - that creates the discursive and affective structures facilitating the development of the particular positive and ambitious aspirations we found at Wagril. We 
Forbes, J. \& Maxwell, C. (2018) 'Bourdieu plus: understanding the creation of agentic, aspirational girl subjects in elite schools', in G. Stahl, D. Wallace, C. Burke \& S. Threadgold (eds) International Perspectives on Theorizing Aspiration: Applying Bourdieu's Tools. London: Bloomsbury.

suggest similar types of dispositions, which legitimate the kinds of futures that come to be expected, will be mirrored across a range of elite education spaces, particularly those in allgirls elite schools (Maxwell and Aggleton 2013a; see also Wardman et al. 2010).

\section{Final Reflections}

This chapter has drawn on the concepts of family and institutional habitus (developed by scholars inspired by Bourdieu) to provide an analysis of how girls' aspirations are fostered and their capacities to pursue these are developed in a very particular school setting. The effects of a privileging institutional habitus configuration, evidencing high levels of socialcultural connectedness and academic excellence, inflected by gender and (upper-middle) social class resources, become a 'forcing ground' for intense cultivation of societally prized dispositions. This secondary - institutionally acquired - habitus underlies Wagril girls' acquisition of socially connected, intellectual, agentic dispositions of 'assured optimism' that carry over to valuably resource their personal and professional futures (Forbes and Lingard 2015).

In Wagril, we found a collective institutional habitus that is very clearly discursively articulated, proactively driven by its headteacher, and practised through its girls' intense and broad - indeed, vast - repertoire of activities and experiences. In this way, the habitus is intensively layered in and through the daily, weekly and annual repetitive intensive rhythms and flows of school: particular tightly timetabled yet naturalized spatio-temporal regimes of learning in formal academic work, and informally through sport, community engagements and social relations. The institutional secondary habitus actively mediates, makes malleable and builds upon the individual family-conditioned primary habitus possessed by each girl. The primary-family and secondary-school spatio-temporal habitus engagements strongly 
Forbes, J. \& Maxwell, C. (2018) 'Bourdieu plus: understanding the creation of agentic, aspirational girl subjects in elite schools', in G. Stahl, D. Wallace, C. Burke \& S. Threadgold (eds) International Perspectives on Theorizing Aspiration: Applying Bourdieu's Tools. London: Bloomsbury.

underlie the (re)production of and future possibilities for agency so effectively because they durably align.

While, for many, there is a relatively seamless knitting together of family and institutional habitus, which is, we argue, especially critical in ensuring the social reproduction fostered successfully by elite schooling, we found some cases of seemingly almost unbridgeable non-alignment of (working-class) family habitus and (upper-middle and middle-class) institutional habitus. Similarly, the institutional habitus could not adequately connect to or overlay the individual needs of a bright girl with autism. In such examples of inadequate primary-secondary habitus alignment, anterior dispositions survive, if somewhat altered. Thus, in these few cases the secondary (institutional) habitus has proven insufficiently malleable to take up and integrate the initial family disposition and overlay these with the necessary resources (capitals) to fully secure a set of the right kind of dispositions for Wagril graduates. Moving beyond school may therefore be less predictable and more fraught than for 'normal' Wagrilians. Gaztambide-Fernández et al. (2013) draw on Ahmed's work to explain how such experiences of non-alignment can lead to students feeling like 'affect aliens'; while Maxwell and Aggleton (2014b) show how non-alignment makes the social reproduction of privilege less secure and unpredictable.

We found Bourdieu's theoretical toolbox - particularly the concept of habitus - to be central in this endeavour. Yet, like research colleagues, often within the Anglophone world, tend to, we have found we need to draw on other theoretical ideas - such as agency, affect and spatio-temporalities - to offer a more in-depth analysis of how elite school social and intellectual (re)production is usually so effective in laying down dispositions that are likely to facilitate the fulfilment of particular articulations of future aspirations. Using a 'Bourdieu plus' conceptual approach, we draw on the foundational ideas in Bourdieusian theory as the framework within which we situate the development of our research and therefore our 
Forbes, J. \& Maxwell, C. (2018) 'Bourdieu plus: understanding the creation of agentic, aspirational girl subjects in elite schools', in G. Stahl, D. Wallace, C. Burke \& S. Threadgold (eds) International Perspectives on Theorizing Aspiration: Applying Bourdieu's Tools. London: Bloomsbury.

analysis, but overlay this with other concepts to help make greater sense of our data.

Methodologically we have found that this hybrid approach offers analytical flexibility which we see as generative of new and nuanced insights into Wagril's structuring conditions - the spatio-temporalities across which its girls' habitus agentically, affectively and reflexively operates.

\section{Recommended Further Reading}

Kenway, J. and A. Koh (eds) (2017), New Sociologies of Elite Schooling, London: Routledge. Maxwell, C. and P. Aggleton (eds) (2013), Privilege, Agency and Affect: Understanding the Production and Effects of Action, Basingstoke: Palgrave MacMillan.

Maxwell, C. and P. Aggleton (eds) (2016), Elite Education: International Perspectives, London: Routledge.

\section{References}

Adams, M. (2006), 'Hybridizing Habitus and Reflexivity: Towards an Understanding of Contemporary Identity?', Sociology, 40 (3): 511-28.

Ahmed, S. (2010), 'Happy Objects', in G. J. Seigworth and M. Gregg (eds), The Affect Theory Reader, 29-51. Durham, NC and London: Duke University Press.

Archer, M. S. (2003), Structure, Agency and the Internal Conversation, Cambridge: Cambridge University Press.

Archer L., J. DeWitt, J. Osborne, J. Dillon, B. Willis and B. Wong (2012), 'Science Aspirations, Capital, and Family Habitus', American Educational Research Journal, 49 (5): 881-908. 
Forbes, J. \& Maxwell, C. (2018) 'Bourdieu plus: understanding the creation of agentic, aspirational girl subjects in elite schools', in G. Stahl, D. Wallace, C. Burke \& S. Threadgold (eds) International Perspectives on Theorizing Aspiration: Applying Bourdieu's Tools. London: Bloomsbury.

Atkinson, W. (2011), 'From Sociological Fictions to Social Fictions: Some Bourdieusian Reflections on the Concepts of "Institutional Habitus" and "Family Habitus", British Journal of Sociology of Education, 32 (3): 331-47.

Bian, L, S.-J. Leslie and A. Cimpian (2017), 'Gender Stereotypes about Intellectual Ability Emerge Early and Influence Children's Interests', Science, 355 (6323): 389-91.

Bourdieu, P. (1977), Outline of a Theory of Practice, Cambridge: Cambridge University Press.

Bourdieu, P. (1986), 'The Forms of Capital', in J. Richardson (ed.), The Handbook of Theory and Research for the Sociology of Education, 241-58, Westport, CT: Greenwood.

Burke, C. T., N. Emmerich and N. Ingram (2012), 'Well-Founded Social Fictions: A Defence of the Concepts of Institutional and Familial Habitus', British Journal of Sociology of Education, 34 (2): 165-82.

Clegg S. (2013), 'The Space of Academia: Privilege, Agency and the Erasure of Affect', in C. Maxwell and P. Aggleton (eds), Privilege, Agency and Affect, 71-87, Basingstoke: Palgrave Macmillan.

Forbes, J. and B. Lingard (2013), 'Elite School Capitals and Girls' Schooling: Understanding the (Re)production of Privilege through a Habitus of Assuredness', in C. Maxwell and P. Aggleton (eds), Privilege, Agency and Affect: Understanding the Production and Effects of Action, 50-68, London: Palgrave MacMillan.

Forbes, J. and B. Lingard (2015), 'Assured Optimism in a Scottish Girls' School: Habitus and the (Re)production of Global Privilege', British Journal of Sociology of Education, 36 (1): 116-36.

Forbes, J. and G. Weiner (2008), 'Understated Powerhouses: Scottish Independent Schools, Their Characteristics and Their Capitals', Discourse: Studies in the Cultural Politics of Education, 29 (4): 509-25. 
Forbes, J. \& Maxwell, C. (2018) 'Bourdieu plus: understanding the creation of agentic, aspirational girl subjects in elite schools', in G. Stahl, D. Wallace, C. Burke \& S. Threadgold (eds) International Perspectives on Theorizing Aspiration: Applying Bourdieu's Tools. London: Bloomsbury.

Forbes, J. and G. Weiner (2012), 'Spatial Paradox: Educational and Social In/exclusion at St Giles', Pedagogy, Culture \& Society, 20 (2): 273-93.

Forbes, J. and G. Weiner (2014), 'Gender Power in Elite Schools: Methodological Insights from Researcher Reflexive Accounts', Research Papers in Education, 29 (2): 172-92. Gaztambide-Fernández, R., K. Cairns and C. Desai (2013), 'The Sense of Entitlement', in C. Maxwell and P. Aggleton (eds), Privilege, Agency and Affect, 32-49, Basingstoke: Palgrave Macmillan.

Lefebvre, H. (1991), The Production of Space, trans. D. Nicholson-Smith, Oxford: Blackwell.

Lefebvre, H. (2004), Rhythmanalysis: Space, Time and Everyday Life, trans. S. Eldon and G. Moore, London: Continuum.

Massey, D. (1994), Space, Place and Gender, Cambridge: Polity Press.

Maxwell, C. and P. Aggleton (2013a), 'Becoming Accomplished: Concerted Cultivation Among Privately Educated Young Women', Pedagogy, Culture \& Society, 21 (1): 7593.

Maxwell, C. and P. Aggleton (2013b), 'Introduction: Privilege, Agency and Affect Understanding the Production and Effects of Action', in C. Maxwell and P. Aggleton (eds), Privilege, Agency and Affect: Understanding the Production and Effects of Action, 1-14, Basingstoke: Palgrave MacMillan.

Maxwell, C. and P. Aggleton (2013c), 'Privilege, Agency and Affect: Moving Further Debate', in C. Maxwell and P. Aggleton (eds), Privilege, Agency and Affect: Understanding the Production and Effects of Action, 248-57, Basingstoke: Palgrave Macmillan.

Maxwell, C. and P. Aggleton (2014a), 'Agentic Practice and Privileging Orientations Among Privately Educated Young Women', Sociological Review, 64 (2): 800-20. 
Forbes, J. \& Maxwell, C. (2018) 'Bourdieu plus: understanding the creation of agentic, aspirational girl subjects in elite schools', in G. Stahl, D. Wallace, C. Burke \& S. Threadgold (eds) International Perspectives on Theorizing Aspiration: Applying Bourdieu's Tools. London: Bloomsbury.

Maxwell, C. and P. Aggleton (2014b), 'The Reproduction of Privilege: Young Women, the Family and Private Education', International Studies in Sociology of Education, 24 (2): 189-209.

Nespor J. (2014), 'Schooling for the Long-Term: Elite Education and Temporal Accumulation', Zeitschrift für Erziehungswissenschaft, 17 (3 Supp): 27-42.

Reay, D. (1998), ““Always Knowing” and "Never Being Sure”: Familial and Institutional Habituses and Higher Education Choice', Journal of Education Policy, 13 (4): 519-29. Reay, D. (2004), “'It’s All Becoming Habitus”: Beyond the Habitual Use of Habitus in Educational Research', British Journal of Sociology of Education, 25 (4): 431-44.

Tarabini, A., M. Curran and C. Fontdevila (2016), 'Institutional Habitus in Context:

Implementation, Development and Impacts in Two Compulsory Secondary Schools in Barcelona', British Journal of Sociology of Education, online before print 22

November. doi:10.1080/01425692.2016.1251306

Threadgold, S. and P. Nilan (2009), 'Reflexivity of Contemporary Youth, Risk and Cultural Capital', Current Sociology, 57 (1): 47-68.

Sweetman, P. (2003), 'Twenty-First Century Dis-ease? Habitual Reflexivity or the Reflexive Habitus', Sociological Review, 51 (4): 528-49.

Wardman, N., R. Hutchesson, K. Gottschall, C. Drew and S. Saltmarsh (2010), 'Starry Eyes and Subservient Selves: Portraits of "Well-Rounded" Girlhood in the Prospectuses of All-Girl Elite Private Schools', Australian Journal of Education, 54 (3), 249-61. 